\title{
DziaŁalność IzABEli CzARTORYSKIEJ W SŁUŻBIE EDUKACJI MUZEALNEJ I WYCHOWANIA PATRiotyCzNego. Powstanie MuZeóW NARODOWYCH
}

\section{[The activity of Izabela Czartoryska in the service of education and cultivating patriotism. The creation of national museums]}

Su m m ary: In the 21st century, museum education in Poland is developing at a dynamic pace. One can notice the emergence of modern, interactive museums with attractive architecture and rich educational programs (e.g. the Warsaw Rising Museum, the Chopin Museum and the recently opened Museum of the History of Polish Jews POLIN, the Jozef Pilsudski Museum, and the Polish History Museum, which is still under construction). The educational activities are aimed at different target groups, including both organized groups such as school classes or groups of persons with disabilities, as well as individual visitors, such as children, families or the socially excluded.

In the present article, the author depicts the first Polish museum created by private initiative at the turn of the 19th century - a museum created of Princess Izabela Czartoryska (née Countess Flemming) "from the bottom of her heart". This was the period in which Poland had completely disappeared from the map of Europe, having lost its national sovereignty. The contemporary educational dimensions of Polish cultural and museum heritage are particularly important in the context of such historical events particularly the commitment of distinguished Poles and the wider Polish society for the perseverance and survival of Polish culture. Analyzing the origins of Polish museology, including the formation of the first patriotic museums and national patriotic museums abroad (for instance in Rapperswil, Switzerland), the author underlines the importance of these activities for the development of the Polish educational thought, as well as museum and patriotic education.

Keyw ords : museum education, patriotic education, cultural heritage, Polish national museums, cultural education 
Poznając swoją historię, naród utrwala swą samoświadomość i tożsamość.

Jan Paweł Woronicz ${ }^{1}$

Szczególną „myśl o wychowaniu” dla Polski niepodległej można odnaleźć w działalności kolekcjonerskiej i muzealniczej polskiej arystokracji. Istotnym wydaje się być dla nas okres, kiedy w burzliwych zawieruchach wojennych, utraconej niepodległości w końcu XVIII wieku, próbowano ocalić to co było szczególnie wartościowe dla przetrwania narodu - jego kulturę. Kulturę przejawiającą się $\mathrm{w}$ zabytkach, dziełach sztuki, architekturze krajobrazu, wytworach artystów, wytrawnych rzemieślników, myślicieli, poetów, w tworzonych dokumentach prawnych, źródłach pisanych. Artefaktach, które stanowią o trwaniu idei, tradycji, wartości wpisanych w dziedzictwo kultury.

Ochrona dziedzictwa kultury, pamięć o nim i dbałość o jego przekaz następnym pokoleniom, stanowią szczególną wartość wychowawczą i edukacyjną odnosząc się do wartości. Zastane przez człowieka dobra kultury służą rozumieniu zjawisk i procesów, stanowią „rzeczywisty teren prawdziwego życia”, rozwoju samoświadomości, odkrywania tożsamości, kulturowego rozwoju i trwania narodu, cywilizacji. ${ }^{2}$

Dla kultury naszego kraju, narodu, państwa nie bez znaczenia pozostają zabytki, obiekty, dzieła sztuki, artefakty. Z ich bogactwa możemy czerpać nie tylko treści i wartości wychowawcze i kształcące, ale przede wszystkim kształtować pamięć i rozwijać umiejętność zrozumienia teraźniejszości poprze znajomość przeszłości, poszukiwać prawdy, własnej

\footnotetext{
${ }^{1}$ Jan Paweł Woronicz (1757-1829) był przyjacielem rodziny Czartoryskich, autorem poematu Światynia Sybilli (1801), który zadedykował Izabeli Czartoryskiej. Poemat odnosi się do alegorycznego położenia Polski. Narratorowi, opłakującemu straszny los narodu pozbawionego niepodległego bytu, Sybilla wyjaśnia przyczynę klęski i wskazuje drogę do zmartwychwstania, odwołując się do tradycji antycznej: „Nie zagrzebie waszego rodu ta mogiła: Troja na to upadła, aby Rzym zrodziła”. Świątynia Sybilli (inny tytul: Sybilla) Poema historyczne w 4 pieśniach, powst. 1801 (według A. Drogoszewskiego), wyd. bez wiedzy autora F. Bentkowski pt. Sybilla. Poema..., Lwów (Warszawa) 1818; odpis: zobacz poz. 55 t. 1; wyd. następne: wyd. 2 poprawione.

${ }^{2}$ Odniesienie do kultury jako wartości wychowawczej i kształcącej znajdujemy w tekstach przedstawicieli pedagogiki kultury rozwijającej się na przełomie XIX i XX wieku szczególnie w Niemczech; w Polsce na szczególną uwagę zasługują prace S. Hessena, B. Nawroczyńskiego i B. Suchodolskiego; współczesne odczytania pedagogiki kultury dotyczą w dużej mierze wartości, odczytania znaczenia dziedzictwa kultury w edukacji kulturowej. Zob. Cz. Kupisiewicz, Z dziejów teorii i praktyki wychowania, Kraków 2012, J. Gajda, Pedagogika kultury w zarysie, Warszawa 2006, J. Torowska, Edukacja na rzecz dziedzictwa kulturowego: aspekty teoretyczne i praktyczne. Kraków 2008, R. Pater, Miejsce muzeum w edukacji kulturalnej dzieci i młodzieży [w:] Kultura artystyczna w przestrzeni wychowania, red. B. Żurakowski, Kraków 2011, s. 155-178. Rozważania na temat współczesnego rozumienia dziedzictwa kultury w szerszym ujęciu przedstawia K. Kowalski, O istocie dziedzictwa europejskiego - rozważania, Międzynarodowe Centrum Kultury Kraków, Kraków 2013
} 
tożsamości, stawiać pytania i próbować znaleźć odpowiedzi. Ważne przestrzenie poznawania, doświadczania i przeżywania historii, sztuki i dziedzictwa kulturowego stanowią muzea. Muzealnictwo na świecie przeżywa obecnie intensywny rozwój. Badacze mówią o intensywnym „umuzealnianiu świata”, architektura obiektów muzealnych to „ikony” współczesnej kultury (Muzeum Guggenheima w Bilbao), które zapraszają do intensywnych przeżyć, doznań o charakterze intelektualno - emocjonalnym ${ }^{3}$. Turystyka kulturowa i rozwijające się „przemysły kultury” stymulują potrzeby "kolekcjonowania doświadczeń", doświadczania ulotnej wspólnotowości, atomizujących się hybrydowych społeczeństw rozwiniętych cywilizacji ponowoczesności.

W XXI wieku edukacja muzealna w Polsce rozwija się szczególnie dynamicznie, powstają nowoczesne, interaktywne muzea o atrakcyjnej architekturze i bogatym programie edukacyjnym (Muzeum Powstania Warszawskiego, Muzeum Chopina czy nowo otwarte Muzeum Historii Żydów Polskich POLIN, czy nowo otwarte Centrum Solidarności w Stoczni Gdańskiej, aktywnie realizujące programy edukacyjne chociaż jeszcze w trakcie budowy Muzeum Historii Polski, Muzeum Józefa Piłsudskiego w Sulejówku i wiele innych $)^{4}$. Oferta edukacyjna skierowana jest do zróżnicowanych grup odbiorców zarówno grup zorganizowanych np. klas szkolnych jak również odbiorcy indywidualnego, dzieci, rodzin, turystów - obcokrajowców, osób z różnymi dysfunkcjami rozwoju i niepełnosprawnościami, osób społecznie czasowo wykluczonych. ${ }^{5} \mathrm{Na}$ mapie Polski w ostatnich latach pojawily się szczególnie aktywne na tym polu instytucje i ośrodki, które edukacją uczyniły swoją misją i wyzwaniem. Poprzez swoje działania edukacyjne przywracają i podtrzymują pamięć o tych, którzy poprzez dbałość o kulturę narodową, walczyli o suwerenność i utraconą niepodległość. Tworząc kolekcje, pragnęli zachować dla przyszłych pokoleń „pamiątki przeszłości”, nie tylko w sentymentalnej nostalgii, ale w trwaniu kultury widzieli sens ocalenia narodu. „Myśl o wychowaniu dla Polski niepodległej” dobrze rozumiała Izabela z Flemmingów Czartoryska. ${ }^{6}$ Autorka znaczącej szczególnie dla Polski ( ale i dla

${ }^{3}$ http://www.guggenheim-bilbao.es/ dostęp: 20.02.2015.

4 Zob: http://www.1944.pl/, oraz http://www.muzhp.pl/, http://www.polin.pl/, http://chopin.museum/pl, http://www.muzeumpilsudski.pl/ dostęp: 26.02.2015.

${ }^{5} \mathrm{O}$ przyszłości muzeów współczesnych w Polsce prowadzi rozważania M. Borusiewicz, analizując definicje współczesnego muzeum, proponuje definicję muzeum przyszłości, w którym „social inclusion" będzie istotnym programem społecznej edukacji. M. Borusiewicz, Nauka czy rozrywka? Nowa muzeologia w europejskich definicjach muzeum. Kraków 2012, s. 168.

${ }^{6}$ Izabela Czartoryska $(1746$ - 1835) była żoną księcia Adama Kazimierza Czartoryskiego dramatopisarza, krytyka literackiego i teatralnego a przede wszystkim polityka, przywódcy Stronnictwa Patriotycznego, do którego też należała, dawało jej szczególną sposobność rozwijania działań patriotyczno - edukacyjnych w konwencji idei oświeceniowych, do których można zaliczyć 
Europy) kolekcji zbiorów puławskich. Zgromadzone przez Izabelę $\mathrm{z}$ Flemingów Czartoryską obiekty - pamiątki kultury, dzieła sztuki, artefakty miały szczególny cel wychowawczy i patriotyczny, o którym napisała następująco: W tych latach, w których tyle klęsk nas przycisnęło, kiedy nas z rzędu narodów wymazano, mówiłam sobie ze łzami: Ojczyzno! Nie mogłam Cię ochronić, niech Cię przynajmniej uwiecznię. Ta chęć, to uczucie przywiąywahy mnie do życia: wystawiłam wówczas Światynię Pamięci. Zabratam tam pamiątki tej Polski, niegdyś tak świetnej, a wtenczas tak nieszczęśliwej. Dom Gotycki, który zawiera pamiątki zagraniczne, zdawat mi się czczy $i$ mało znaczący, póki nie umieściłam $w$ nim jakiegoś wspomnienia mojej Ojczyzny. ${ }^{7} \mathrm{~W}$ bogatej kolekcji różnorodnych zbiorów Czartoryskich znajdowały się między innymi cenne działo Leonarda da Vinci portret „Damy z gronostajem”, Rafaela „Portret młodzieńca” i Rembrandta „Krajobraz z miłosiernym samarytaninem”. Właściwie przedmiotem kolekcji I. Czartoryskiej były zarówno militaria, zdobycze wojenne, wszelkie artefakty z okresu świetności Polski upamiętniające działania wielkich i znaczących dla historii Polaków miedzy innymi Bolesława Chrobrego. Kazimierza Wielkiego, Stefana Batorego, Jana Zamojskiego, Żółkiewskiego, Czarnieckiego, Lwa Sapiehy i wielu innych. Kolekcjonerskie zamiłowania Czartoryskiej wiązały się z panującym w Europie nurtem idei oświecenia, arystokraci oddawali swe zbiory do publicznego oglądu dla społecznej edukacji. Szczególną inspiracją mogła być działalność kulturalna i oświatowa Stanisława Augusta, obejmując tron w 1764 roku stworzył pomyślniejsze warunki dla rozwoju oświaty w Polsce, skupiał wokół siebie uczonych i literatów i zachęcał ich do podejmowania działań, sprowadzał artystów, gromadził kolekcje i gabinety. Był założycielem Szkoły Rycerskiej w Warszawie, w której „panowała atmosfera oświecona, kadetom wolno było czytać najnowsze dzieła filozoficzne i polityczne, a profesorowie referowali najnowsze osiągnięcia naukowe". ${ }^{8}$ Nie bez znaczenia jest fakt, że funkcję komendanta w tej szkole pełnił książę Adam Czartoryski, a dwór Czartoryskich w Puławach był ogniskiem kultury i oświaty dając wyraz nowoczesnym ideom oświeceniowym.

Wiek XVIII charakteryzowało szczególne zainteresowanie naukami przyrodniczymi, historią, jak również nowe spojrzenie na gromadzone obiekty. Oświecenie przyniosło daleko idące zmiany w udostępnianiu kolekcji szerszemu gronu odbiorców. Istotną przemianę wniósł akt Wielkiej Rewolucji Francuskiej (1789) stanowiący o społecznej przynależności muzeów. W 1793

utworzenie pierwszego muzeum w Polsce, którego pośrednim celem było udostępnienie zebranej kolekcji dla kształcenia przyszłych pokoleń .

${ }^{7}$ A. Kunysz, W stużbie kultury i regionu. Rzecz o muzeum $w$ Przemyślu, Przemyśl 1989, s. 12, [za:] Katalog Domu Gotyckiego, Biblioteka Czartoryskich, rkps 2917, t. I, s. 89.

${ }^{8}$ S. Kot, Historia wychowania, Tom II, Wychowanie nowoczesne. Od połowy wieku XVIII do wspótczesności. Wydanie czwarte (wg wydania trzeciego z 1996 roku). Kraków 2010, s. 61- 64. 
miało miejsce oficjalne otwarcie Luwru pierwotnie zwanego Musee Francais, od 1796 Musee Central des Arts, a po 1804 Musee Napoleon. Zebrano i wystawiono wówczas najlepsze dzieła sztuki Francji i jak na tamte czasy wyeksponowano w rewolucyjny sposób. Wszystkie dzieła były zaprezentowane w sposób systematyczny według szkół. Powodem tego wymagania była nowa idea edukacyjnej roli muzeów. Odnosiła się idei encyklopedystów, umożliwienia edukacji szerszej publiczności, prezentacji roli wpływu starej sztuki na młodych twórców (artystów, malarzy). Po raz pierwszy w historii muzealnictwa, jego funkcja pedagogiczna stanęła na pierwszym miejscu, a muzeum stało się miejscem kształcenia i wychowania. Niebywały rozkwit muzealnictwa $\mathrm{w}$ naszych czasach stał się możliwy właśnie dzięki udostępnieniu i oddaniu muzeów społeczeństwu. Pionierską egzemplifikacją idei XVIII wieku, kiedy rozwijał się nurt racjonalizmu, empiryzmu, utylitaryzmu i humanitaryzmu było utworzenia pierwszego wielkiego muzeum publicznego British Museum w Londynie. Obejmowało ono zbiory biblioteczne, przyrodnicze, a także bogaty dział starożytności. Wiek oświecenia jest nowym ważnym etapem w dziejach europejskiego kolekcjonerstwa i muzealnictwa. ${ }^{9} \mathrm{~W}$ Polsce powstała w tym czasie Biblioteka Publiczna założona przez braci Załuskich, sławną stała się również galeria malarstwa Stanisława Augusta Poniatowskiego. Obejmowała zbiór rzeźb, gemm, monet, medali, grafiki, a także zbiory przyrodnicze, wiele cennych tkanin, mebli itp. Na dworze króla Stanisława Augusta Poniatowskiego narodził się pierwszy projekt autorstwa Stefana Chardon de Rieule, stworzenia muzeum - placówki propagującej rozwój nauk przyrodniczych. Proponowane przez niego muzeum przyrodnicze miało mieć charakter placówki publicznej, przyczynić się do podniesienia poziomu rolnictwa przez spopularyzowanie wiedzy rolniczej. Autor tej śmiałej jak na ówczesne czasy koncepcji dostrzegał i wskazywał trzy zasadnicze wartości społeczne zbiorów muzealnych: oświatowo - dydaktyczne, praktyczno - użytkowe oraz naukowe: dokumentacyjne i badawcze. ${ }^{10}$ Działalność Izabeli Czartoryskiej wynikała z jej szczególnych zainteresowań i umiłowania do kultury. Edukacyjny wydźwięk kolekcji powiązać można $\mathrm{z}$ panującymi wówczas prądami edukacji obywatelskiej i ideami oświecenia przejawiającymi się między innymi $\mathrm{w}$ działalności Komisji Edukacji Narodowej. Głównym przesłaniem jej prac było upaństwowienie szkolnictwa, powszechność kształcenie, zastąpienie szkół prywatnych szkołami państwowymi, wychowanie młodzieży w duchu dobrze pojętego patriotyzmu i edukacji narodowej czyniąc Polaków racjonalnymi obywatelami Polski. Kontestowano absolutyzm i dogmatyzm kleru i władz kościelnych. Istotne miejsce zajmowało wychowanie moralne, kształtowanie

\footnotetext{
${ }^{9}$ Z. Żygulski, op. cit., s. 21.

${ }^{10}$ Ibidem.
} 
cnót, obok wychowania intelektualnego wychowanie fizyczne, które miało hartować ducha. W koncepcjach pedagogicznych Grzegorza Piramowicza odnaleźć można wpływy filozofii liberalizmu J. Locka jak również idei pedagogicznych J.J. Rousseau. Działalność KEN miała wpływ na polityczne i moralne odrodzenie się narodu, jej głównymi działaczami byli Ignacy Potocki, Hugo Kołłątaj, Chreptowicz, Adam Czartoryski, którzy stanęli również na czele stronnictwa reform zwieńczonych w Konstytucji 3 Maja. Upadek Rzeczpospolitej kończy działalność Komisji Edukacji Narodowej jako sternika reform i odnowy społecznej. ${ }^{11}$ Nie bez znaczenia działania KEN okazały się dla działalności polskiej arystokracji, a szczególnie Izabeli Czartoryskiej założycielki pierwszego muzeum w Polsce.

\section{Pamiętając o przeszłości dążyć do niepodległości : Światynia Sybilli i Domek Gotycki}

Pierwsze muzeum w Polsce obejmowało Świątynię Sybilli i Domek Gotycki. Nawiązywało zgodnie z duchem epoki do tradycji starożytnych, jak również do głoszonego przez romantyzm patriotyzmu. Było to przede wszystkim sanktuarium kultury narodowej, zagrożonej w czasach klęsk i rozbiorów, tworzące dokumentację narodowej przeszłości. Szczególna różnorodności i rozpiętość tematyczna zbiorów świadczy o determinacji z jaką próbowano ocalić każdy przejaw polskości i związanych z nią historii.

W Świątyni Sybilli (zwanej również Świątynią Pamięci) znajdowały się przede wszystkim zabytki militariów: ozdobne tarcze, buńczuki tureckie, szyszaki, karwasze, szable, pałasze itp. Zbiory gromadzone były pod kątem ich narodowego wydźwięku. Księżna Czartoryska kładła główny nacisk na skojarzenia historyczne, emocjonalne i moralne, jakie jej zbiory budziły i budzić miały u zwiedzających. ${ }^{12} \mathrm{Na}$ szczególną uwagę zasługuje wydany w tym czasie drukiem przewodnik pt. Poczet pamiatek zachowanych $w$ domu Gotyckim $w$ Pulawach, który był inwentarzem typograficznym liczącym 1531 pozycji, obejmujących około 3000 eksponatów. Każdy przedmiot posiadał swój numer oraz krótki opis, w którym wyszczególnione były: pochodzenie przedmiotu, datowanie, informacje o osobie, od której został nabyty lub ofiarowany. W przewodniku opisane były przedmioty znajdujące się na zewnątrz budynku, jak również obiekty wystawione wewnątrz Domu Gotyckiego, opisane w kolejności poszczególnych pomieszczeń. Wydanie przewodnika przeznaczonego do praktycznego zwiedzania okazało się bardzo istotne dla rozwoju muzealnictwa, a w szczególności dla działalności

\footnotetext{
${ }^{11}$ Por. S. Kot, dz. cyt., s. 61-139.

${ }^{12}$ Por. Z. Żygulski jun, Muzea na świecie. Wstęp do muzealnictwa, Warszawa 1982.
} 
oświatowej (edukacyjne) - popularyzacji wiedzy Oddanie przez Izabellę Czartoryską do użytku publicznego Świątyni Sybilli w Puławach w 1801 roku przyjmuje się za początek okresu polskiego nowożytnego muzealnictwa. ${ }^{13}$ Współcześni badacze problematyki muzealniczej i edukacji muzealnej wskazują na ważny w edukacyjnym procesie wydźwięk kolekcji zbiorów, pamiątek przeszłości dla zrozumienia teraźniejszości, własnej tożsamości i zmiennych losów historii, które ukształtowały obecną rzeczywistość. Włączenie i uprzystępnienie społeczeństwu, każdemu obywatelowi dziedzictwa kultury, stanowi nie tylko wyzwanie dla przyszłości, ale przede wszystkim potrzebą teraźniejszości, w której zagrożona jest tożsamość jednostki, jej prawo do poznania i pielęgnowania narodowej kultury, do wolnego wyboru, do wolności, równego traktowania, demokracji. Odcinanie się od przeszłości, ignorancja kultury, dziedzictwa kulturowego, to odwracanie się od wartości, które budowały pokolenia i pozwalały im trwać we wspólnotowości języka, obyczaju, dając siłę przetrwania.

Postulaty oświeceniowe wskazywały na wagę edukacji jako motoru wszelkiej zmiany, położenia człowieka, wyznaczając i niejako współokreślając możliwości rozwoju, kształtowania siebie i własnego życia. Wiedziała o tym również Izabela Czartoryska nie tylko prowadząc w posesji pałacowej prywatne pensje dla dzieci książąt, arystokracji i niebogatej szlachty, ale przede wszystkim zakładając sieć szkół elementarnych i zawodowych dla dzieci wiejskich. Były to działania wynikające z ówczesnych idei oświecenia, którego szczególny wydźwięk przejawiał się w reformie szkolnictwa i w spopularyzowaniu hasła „oświaty ludu”14. Wspierała ją w tych działaniach jej córka Marią Wirtemberską oraz syn Adam Jerzy. Należy podkreśli, że były to działania prekursorskiej idei pozytywistycznej skierowane do tej grupy wówczas społecznie wykluczonej z dostępu do edukacji. Powstało równie Towarzystwo Szkolne, zaplanowano budynki szkolne, których autorem był prawdopodobnie Chrystian Piotr Aigner - nadworny architekt Czartoryskich (niektóre źródła podają nazwisko architekta Daniela Ruprechta). W pierwszej połowie XIX wieku (1824) we Włostowicach funkcjonowały następujące szkoły:

- Szkoła Elementarna dla chłopców, w której naukę pobierało przeszło 70 uczniów, przekazywano umiejętności czytania i pisania, podstawy religii, nauki moralnej, i umiejętności związanych z pracą w gospodarstwie i na roli Szkoła Gospodarstwa Domowego dla dziewcząt zwana Szkołą św. Zofii, skupiająca głównie sieroty, uczono w niej czytania i pisania jak również prac

13 J. Samek, Dzieje sztuki polskiej dla pedagogów, Kraków - Przemyśl 1999, s. 110, por. Z. Żygulski, Dwieście lat muzeum Czartoryskich [w:] Spotkania z muzeami, Dodatek do „Spotkań z zabytkami”, Warszawa 2001, nr 3, s. 4.

${ }^{14}$ S. Kot, op. cit., s. 48 
domowych: szycia, cerowania, haftu i gotowania. Szkoła zwana inaczej Domem Robót, kształcąca chłopców w zawodach rolniczych i i rzemieślniczych (kowalstwo, ślusarstwo, stolarstwo itp.). Przy kościele parafialnym we Włostowicach działała wówczas również szkoła śpiewu. Do kadry pierwszych pedagogów należy zalicza się Antoniego Amborskiego (nauczyciela szkoły męskiej) i Agnieszkę Baraniecką (nauczycielkę szkoły żeńskiej). ${ }^{15}$

Podkreślić należy, że działania podejmowane przez Czartoryskich wyrażały idee ówczesnej oświeceniowej filozofii utylitarnego humanitaryzmu. Ówczesna pedagogika szkolna wyrażała zdobycze myśli naukowej, filozoficznej, moralnej i politycznej, nauk przyrodniczych, badań językowych, nowej psychologii i logiki. W zakresie społecznym postulowano potrzebę kształcenia kobiet i stanów niższych, to właśnie w tym czasie sformułowano pojęcie pracy oświatowej jako społecznego obowiązku.

Działalność księżnej Czartoryskiej przejawiała się również w jej twórczości pisarskiej, literackiej. Księżna pisała książki, których odbiorcami były wiejskie dzieci Książka do pacierzy dla dzieci wiejskich podczas Mszy Świętej dla szkólki puławskiej napisana (1815). Pozycja ta została wznowiona w 1821 roku oraz wydana w drukarni Czartoryskich w 1830 roku. Oprócz oryginalnych tekstów modlitw autorstwa księżnej Izabeli, zawiera m.in. Pieśń Jana Kochanowskiego Czego chcesz od nas Panie. Dydaktyczny wymiar treści patriotycznych wyłania się z książki Pielgrzym $w$ Dobromilu czyli nauki wiejskie z dodatkiem powieści i 40 obrazkami (1819). Ilustracje przedstawiały królów polskich. Pisane przez Czartoryską quazi podręczniki prezentowały nie tylko wiedzę historyczną, ale zawierały przede wszystkim treści wychowawcze, prezentowane w duchu demokracji, uczyły o tolerancji, a nawet szacunku dla przyrody. Kolejny zbiór Pielgrzym $w$ Dobromilu, część druga, czyli dalszy ciąg nauk wiejskich z dziesięciq obrazkami i muzykq ukazał się w 1821 roku. I. Czartoryska była też autorką libretta śpiewogry „Pielgrzym z Dobromila”. Wydanie tych prac zaopatrzonych $\mathrm{w}$ obrazy i muzykę, porównywano ze Śpiewami historycznymi Juliana Ursyna Niemcewicza. Księżna Czartoryska zainicjowała również wydawanie zeszytów dla dzieci - Skarbiec dla dzieci (zeszyty drukowano w prywatnej drukarni Czartoryskich, która funkcjonowała w latach 1828 - 1831), fundowała stypendia dla uzdolnionych uczniów. Po opuszczeniu przez Księżną Puław szkoły znacznie podupadły, z trzech pozostała tylko jedna funkcjonująca pod nazwami szkoła powszechna lub szkoła podstawowa. Uczęszczały do niej dzieci z okolicznych Włostowic i Parchatki. Budynek szkolny przetrwał czas rusyfikacji, burzliwy okres wojny i okupacji i służył włostowickiej młodzieży aż do roku 1969. Później popadł w

\footnotetext{
${ }^{15}$ Por. 2. S. Jednacz , Pięć lat Muzeum Oświatowego w Puławach. Biul. Inf. Sam. M. Puławy 1992, nr 10 s. 1-3, oraz http://www.ssmpulawy.pl/muzeum.html\#25, dostęp: 25.02.2015. Zob. I. Czartoryska, Pielgrzym w Dobromilu czyli nauki wiejskie z dodatkiem powieści. Cz. 1, nakładem N. Glücksberga, księgarza i typografa Królewskiego Uniwersytetu Warszawa 1830.
} 
ruinę. Dopiero w latach 80 - tych XX wieku zabytkowym budynkiem puławskim zainteresował się Jerzy Żurawski, konserwator zabytków i dyrektor Muzeum Nadwiślańskiego w Kazimierzu Dolnym nad Wisłą. Przeciwstawił się próbom zburzenia podupadającego obiektu, a upamiętnienie historii oświaty dokonało się dzięki zaangażowaniu nauczycieli Stanisław Jędrycha i Stanisława Jednacza, którzy przyczynili się do przygotowywania pierwszej wystawy przyszłego Muzeum Oświatowego. Wystawę odwiedziło od maja 1986 roku do lutego 1987 roku około 100 nauczycieli. Uroczyste otwarcie Muzeum nastąpiło 27 lutego 1987. Pierwsza wystawa przedstawiała 230 eksponatów, kolekcję podzielono tematycznie: kształcenie i dokształcanie nauczycieli, zatrudnianie, praca lekcyjna i pozalekcyjna, podręczniki i czasopisma, pomoce naukowe, administracja oświatowa oraz działalność związkowa. Zaprezentowano historię puławskiej oświaty i szkolnictwa, zwracając szczególną uwagę na ofiarodawców, podkreślając tym samym rolę tradycji i rangę dziedzictwa kulturowego. W początkowym okresie funkcjonowania jednostka działała pod nazwą Regionalne Muzeum Oświaty i podlegała Wydziałowi Oświaty i Wychowania w Puławach, od 1997 roku funkcjonuję pod nazwą Muzeum Oświatowe i jest pod zarządem Starostwa Powiatowego. Obecnie przy placówce działa Towarzystwo Przyjaciół Muzeum Oświatowego, skupiając nauczycieli, pasjonatów i miłośników Puław. W ten sposób podtrzymywana jest tradycja myśli oświatowej I. Czartoryskiej. Jak można przeczytać na stronie www, „Puławskie Muzeum Oświatowe oprócz pokaźnej dawki historii przekazuje idee postannictwa i misji zawodu nauczyciela, która $w$ obecnych czasach biurokratyzacji tej profesji odchodzi powoli $w$ zapomnienie. Czy więc pulawskie Muzeum Oświatowe jest ostatnią twierdza upadajacego etosu nauczyciela..."16

Muzealnicza i edukacyjna działalności Izabeli Czartoryskiej wynikała z jej zainteresowań kulturą, sztuką i troską o przyszłość ojczyzny i narodu. Kolekcjonerska pasja została przez nią wykorzystana dla edukacyjnych celów o znaczącym wymiarze patriotycznym i narodowy. W innych inicjatywach muzealniczych również można odnaleźć narodowego ducha tamtych czasów.

\section{Muzea narodowe w edukacji przyszłych pokoleń Polaków}

Walka o przetrwanie polskości znalazła swój wymiar również w gromadzeniu zbiorów i eksponowaniu ich poza granicami kraju. Dla polskiego dziedzictwa narodowego istotne znaczenie mają instytucje muzealne, które

\footnotetext{
${ }^{16}$ http://www.tubapulaw.pl/aktualnosci/czytaj/169/MUZEUM-OSWIATOWE-WPUIAWACH-TWIERDZA-ETOSU-NAUCZYCIELA., s.1, dostęp:25.02.2015, por. A. Maj, Muzeum Oświatowe w Puławach (1987-1997) - zarys monograficzny, Puławy 1997.
} 
powstały za granicą. W 1869 roku z inicjatywy Władysława Platera utworzono Muzeum Historyczne Polskie w Rapperswilu (Szwajcaria). Założenie muzeum w Rapperswilu miało cel patriotyczny, miała to być instytucja publiczna, chociaż zorganizowana i finansowana przez osobę prywatną. Organizatorzy planowali również utworzenie Towarzystwa Muzealnego, które zjednoczyć miało wszystkie muzea w Europie i Ameryce w celu podniesienia umiejętności muzealnych. Zadaniem towarzystwa miało być także przeprowadzenie konwencji międzynarodowej: zobowiązującej na wypadek wojny strony wojujące do pokrycia bandera neutralności wszystkich tego rodzaju instytucji naukowych. Był to pierwszy projekt $\mathrm{w}$ historii światowego muzealnictwa dotyczący uregulowań prawnych ochrony dóbr kultury, jak również początek $\mathrm{w}$ specjalizacji $\mathrm{w}$ muzealnictwie (muzea przyrodnicze, muzea narodowe). W 1872 roku został wydany katalog zbiorów opracowany w trzech językach: polskim, francuskim i niemieckim. ${ }^{17}$

W pierwszej połowie XIX wieku w Polsce, znajdującej się pod zaborami, nie było warunków i muzea publiczne nie powstawały, jak to miało miejsce w tym czasie w innych krajach Europy. Najważniejsze osiągnięcia w muzeologii polskiej tego czasu ewoluowały na jednak rzecz społeczeństwa i jego edukacji. Antoni Kunysz scharakteryzował je następująco:

- skonkretyzowanie się potrzeby i wykrystalizowanie koncepcji publicznego muzeum jako placówki dokumentacyjnej i oświatowej z programem obejmującym wszystkie dziedziny humanistyki, przyrody i techniki

- wyznaczenie muzeum zadań politycznych, akcentujących cele narodowe, realizowane na podstawie reliktów przeszłości i wzorów współczesnych osiągnięć, gromadzonych, zabezpieczanych i udostępnianych dla pogłębienia patriotyzmu, rozwoju i popularyzacji wiedzy oraz zapewnienia postępu, szczególnie w dziedzinie gospodarki narodowej

- ukształtowanie się profilu i wymagań kwalifikacyjnych, jakim odpowiadać powinien pracownik muzealny: wykształcenie uniwersyteckie $\mathrm{w}$ zakresie dyscypliny reprezentowanej przez daną placówkę, uzupełniane wiedzą specjalistyczną, muzeologiczną, uzyskaną drogą praktyki i studiów $\mathrm{w}$ wiodących placówkach zagranicznych; rozwinięcie wiedzy tak, aby kandydat mógł być wykładowcą na uczelniach wyższych, prowadzić samodzielnie prace naukowe i publikować wyniki swoich badań. Do tych fachowych

${ }^{17}$ K. Stachursk i, Dziedzictwo narodowe Polaków poza granicami kraju. [w:] Dodatek do „Spotkań z zabytkami”, Warszawa 2001, nr 5, s. 6. Oraz por. http://www.muzeum-polskie.org/mpr/polski/historia.html, dostęp: 25.02 2015. Zob. „140 lat Muzeum Polskiego /140 Jahre Polenmuseum/ Rapperswil 1870-2010”, http://issuu.com/muzeumpolskie/docs/historia_muzeum_listopad_2010, dostęp:25.02.2015. 
kwalifikacji dochodzą wymagania natury moralnej: poczucie odpowiedzialności, bezinteresowność, uczciwość i sumienność

- pojawienie się aktu normatywnego, jakim jest Instrukcja dla Gabinetu Numizmatycznego, który akcentuje bezpieczeństwo zbiorów i odpowiedzialność, niezależnie od tego, że określa omówione $\mathrm{w}$ poprzednim punkcie wymagania kwalifikacyjne. Instrukcja ta jest wyrazem szybko postępującego procesu instytucjonalizowania się muzeum wyrosłego na społecznopaństwowej bazie organizacyjnej i wyodrębnienia muzeum jako placówki o swoistej specyfice rządzącej się własnymi, odrębnymi prawidłami

- pojawienie się przewodników drukowanych, które są wyrazem narastających tendencji do zaktywizowania społeczno-oświatowej funkcji muzeum

Przytoczone fakty są wyraźną zapowiedzią wykształcenia się nowej dyscypliny - muzeologii, której rozwój przejawił się w okresie niezwykle bujnego rozkwitu towarzystw naukowych i regionalnych oraz placówek naukowo - badawczych. ${ }^{18}$ Zapoczątkowany $\mathrm{w}$ drugiej połowie XIX wieku rozwój muzeów narodowych szczególnego znaczenia i rangi nabrał na początku wieku XX, na co wskazuje utworzenie licznych muzeów regionalnych (prowincjonalnych - krajoznawczych) poświeconych głównie obrazowaniu kultury i przyrody danego okręgu. ${ }^{19}$

W Krakowie w drugiej połowie XIX wieku powstało kilkanaście placówek muzealnych, bogatych zbiorów bibliotecznych, archiwów świeckich i kościelnych. Jedną z najstarszych placówek muzealnych Krakowa stało się Muzeum Archeologiczne. W 1878 roku oficjalnie otwarte zostało Muzeum Czartoryskich (zbiory uratowane i przechowane w Hotelu Lambert przez syna Izabeli Czartoryskiej Adama Jerzego. O randze utworzonego muzeum świadczą zgromadzone dzieła sztuki malarstwa światowego, w tym rysunki i obrazy mistrzów zachodnioeuropejskich: A. Dürera, Rembrandta, zabytki sztuki starożytnej, średniowiecznej, rzemiosło artystyczne, wspaniała kolekcja broni, porcelany, szkła, tkanin itp. ${ }^{20}$

W drugiej połowie XIX wieku stało się modne organizowanie tzw. muzeów przemysłowych. Najstarszym jest założone w 1868 roku przez dr Adriana Baranieckiego, oddane do użytku społeczeństwa w 1895 Muzeum Przemysłowe Miejskie w Krakowie. Gromadziło ono zbiory głównie z zakresu sztuki stosowanej, składające się z modeli maszyn i przyrządów, z okazów

\footnotetext{
${ }^{18}$ A. Kunysz, op. cit., s. 15 .

${ }^{19}$ M. Sołtysiak, Polskie muzea regionalne [w:] Dodatek do „Spotkań z zabytkami”, Warszawa 2001, $\mathrm{nr} 6$.

${ }^{20}$ J. Samek, op. cit., s. 110, por. Z. Żygulski,, Dwieście lat muzeum Czartoryskich [w:] Spotkania z muzeami, Dodatek do „Spotkań z zabytkami”, Warszawa 2001, nr 3, s. 4.
} 
materiałów surowych i bogatego zbioru strojów ludowych - liczyło ok. 40 tys. eksponatów. W 1913 roku oddano do użytku muzeum specjalnie w tym celu wybudowany budynek.

Gdy w XIX wieku powstają w Europie narodowe muzea, biblioteki, teatry, również w nieistniejącej na ówczesnej oficjalnej mapie Europy Polsce, tworzone są tego typu placówki. Z inicjatywy prezydenta Krakowa Józefa Dietla w październiku 1879 roku Rada Miasta Krakowa, uchwaliła powołanie pierwszego polskiego Muzeum Narodowego, które mogłoby być: pocieszycielem $w$ chwilach zwątpienia, skarbcem narodowych uczuć $i$ przybytkiem dziet sztuki siejącym zgodę i miłość. Było to podjęcie myśli, którą wysuwali 100 lat wcześniej S. August Poniatowski, Michał Wandalin Mniszech, Izabela z Flemingów Czartoryska.

Utworzenie Muzeum Narodowego w Krakowie było możliwe ze względu między innymi na przejęcie mecenatu nad sztuką z rąk arystokracji przez mieszczaństwo, które nie posiadało środków, aby utworzyć muzea prywatne i popierało ideę muzeów publicznych. Kraków - centrum ośrodka naukowego i artystycznego w Polsce - stał się siedzibą pierwszego muzeum publicznego o charakterze ogólnonarodowym. W ten sposób wyrażono przekonanie, że na jego powstanie złożył się cały naród, a muzeum gromadzić będzie zabytki ukazujące przeszłość historyczną i artystyczną całego narodu oraz twórczość bieżącą. ${ }^{21}$ Początkowo muzeum gromadziło tylko dzieła sztuki. Wybór ten zgodny był z wyznawaną wówczas romantyczną skalą wartości i stwarzał najlepszą szansę powstania w dalszej perspektywie monumentalnej kolekcji na podobieństwo wielkich muzeów artystycznych w innych krajach europejskich. Zrezygnowano początkowo ze zbierania w Muzeum Narodowym przedmiotów historycznych i pamiątek niemających charakteru sztuki, sądzono, że powinny pozostać $\mathrm{w}$ polu zainteresowania muzeów specjalizujących się w tych dziedzinach, których zresztą zaczątki już istniały. Decyzja ta na długie lata przesądziła o głównych zadaniach Muzeum Narodowego w Polsce, a wypływała z faktu, że zakładano tę instytucję bez oparcia się na istniejącej jakiejkolwiek kolekcji. Dopiero, gdy w XX wieku funkcję dyrektora Muzeum Narodowego objął Feliks Kopera poszerzony został repertuar zainteresowań muzeum o zabytki kultury i historyczne. Do wybuchu drugiej wojny światowej Muzeum Narodowe w Krakowie pozostawało czołową instytucją muzealną w Polsce. ${ }^{22} \mathrm{~W}$ jego skład weszły później oddziały: Muzeum Czapskich (1903), Muzeum Jana Matejki (1904), Barbakan oraz Brama Floriańska. $^{23}$

\footnotetext{
${ }^{21}$ A. Kopff, Muzeum Narodowe w Krakowie. Historia i zbiory, Kraków 1962, s. 38.

${ }^{22}$ T. Chruścicki, Spotkania z muzeami. O muzeach narodowych $w$ Polsce [w:] Dodatek do „Spotkań z zabytkami”, lipiec 2001, s. 1.

${ }^{23}$ S. Lorentz, Przewodnik po muzeach i zbiorach w Polsce, Warszawa 1973, s. 27-32.
} 
Wiek XIX to bujny rozkwit nauk historycznych w całej Europie. Zwyciężył wówczas pogląd, że nowa kultura musi nawiązywać do dawnej, a nie poprzestawać na szukaniu wyłącznie nowych postaw. Projektowane muzea miały stać się namacalnym przykładem świetnej przeszłości, przemawiającej wprost do uczuć.

Jednak należy wziąć pod uwagę fakt, że muzea powstające w Europie i noszące w swej nazwie przymiotnik narodowe nie we wszystkich przypadkach miały to samo znaczenie. Jak pisze Jerzy Banach: Nazwa "muzeum narodowe" nie wszędzie i nie zawsze ma to samo znaczenie. $W$ niektórych krajach nazwa ta wskazuje, że instytucja muzealna należy do państwa, $w$ przeciwstawieniu na przykład do muzeów miejskich. Winnych, że chodzi o muzeum $w$ danym kraju najważniejsze, jedyne o tej randze. Może to być muzeum sztuki powszechnej lub przeciwnie, sztuki czy kultury jednego kraju. $^{24}$

W Polsce kolejne muzea narodowe powstać mogły dopiero w XX wieku, po uzyskaniu przez Polskę niepodległości. W 1916 roku Muzeum Sztuk Pięknych w Warszawie, powołane ustawą o wychowaniu publicznym z 20 maja 1862 roku przemianowano na Muzeum Narodowe. Kolejne muzea w Polsce przyjmowały nazwę Muzeów Narodowych dopiero po drugiej wojnie światowej (w 1950 Muzeum Wielkopolskie w Poznaniu, w 1970 Muzeum Śląskie we Wrocławiu oraz Muzeum Pomorza Zachodniego w Szczecinie, w 1972 Muzeum Pomorskie w Gdańsku, w 1975 Muzeum Świętokrzyskie w Kielcach), przy czym należy zaznaczyć, że Muzea Narodowe w Krakowie, Warszawie i Poznaniu pozostają do dziś muzeami państwowymi, pod bezpośrednią opieką rządu Rzeczpospolitej. Wśród instytucji muzealnych pełniących funkcję narodowych należy również wymienić główne polskie rezydencje monarsze: Zamek Królewski na Wawelu i Zamek Królewski w Warszawie czy Pałac w Wilanowie. Obecnie Muzea Narodowe należą do najprężniej działających instytucji o charakterze nie tylko kulturalnym ale przede wszystkim edukacyjnym.

\section{Zakończenie}

Edukacja muzealna $\mathrm{w}$ proponowanym namyśle, zainicjowana poniekąd przez Izabellę Czartoryską w jej myśli wychowania patriotycznego i narodowego, przejawiała się w działaniach patriotów, strażników polskiej kultury, narodowości, w tradycji pamiętania, trwania dziedzictwa kultury pokoleń, które łączyła nie tylko wspólnota kulturowa, język, wierzenia, tradycja czy religia, ale przede wszystkim wyrażana była w kulturze myśli, w

${ }^{24}$ cyt. za T. Chruścicki, Spotkania z muzeami. O muzeach narodowych w Polsce [w:] Dodatek do „Spotkań z zabytkami”, lipiec 2001, s. 1. 
dziełach sztuki i artefaktach kulturowych, świadcząc o specyfice polskiej kultury i jej burzliwej historii. „Myśl o wychowaniu dla Polski niepodległej” odsłania się w działaniach edukacyjnych, ochronie dziedzictwa kulturowego Polski i Europy realizowanych z odwagą, pasją i poświęceniem zarówno przez Izabelę Czartoryską jak również wszystkich tych, którzy przyczyniali się do ochrony i utrwalania historycznego dziedzictwa Polski w muzealnych instytucjach. Jaka byłaby dzisiaj kultura Polski bez zbiorów puławskich, Świątyni Sybilli i Domku Gotyckiego, bez Muzeum Książąt Czartoryskich w Krakowie czy też Muzeum Polski w Rapperswilu oraz licznych zbiorów Muzeów Narodowych czy regionalnych? Trudno jest odpowiedzieć na tak postawione pytanie. Badania nad dziedzictwem kultury mają współcześnie charakter wielowymiarowy i interdyscyplinarny. Jednak trudno nie doceniać ich znaczenia dla społecznej edukacji i rozwoju kultury. Interpretując dziedzictwo kultury dzięki ocalałym zabytkom i muzealiom możemy dzisiaj w ich kontekstach poznawać przeszłości, historię, próbować odczytać naszą narodową tożsamość (chociaż nie bez spornych dyskusji), twórczo kreować przyszłość. Muzea dzisiaj mogą wykorzystać w pełni swój potencjał pełniąc ważną funkcję edukacyjna (wychowawczą i kształcącą) wprowadzając kolejne pokolenia w arkany historii sztuki, ukazując blaski i cienie, klęski i triumfy minionych pokoleń $\mathrm{w}$ kontekście obecnych zmagań $\mathrm{z}$ codziennością, proponując przestrzeń wspólnotowego świętowania Polski niepodległej (np. podczas Nocy Muzeów). ${ }^{25}$

„Przeszłość - Przyszłości”. Ta myśl wychowawcza w kontekście przedstawionej historii powstania pierwszych muzeów narodowych, świadczy o wartości idei potrzeby wolności wyłaniającej się z naszego dziedzictwa przeszłości. W tym kontekście szczególnie ważna wobec wyzwań przyszłości jawi się współczesna edukacja kulturalna, historyczna - muzealna dzieci i młodzieży, aby poznając swoja historię, naród utrwalat swa samoświadomość i tożsamość. ${ }^{26}$

\footnotetext{
${ }^{25} \mathrm{http}: / /$ www.krakowskienoce.pl/noc_muzeow/82762,artykul,glowna.html, dostęp 25.02.2015.

${ }^{26}$ Jan Paweł Woronicza(1757-1829) był przyjacielem rodziny Czartoryskich, autorem poematu Świątynia Sybilli (1801) , który zadedykował Izabeli Czartoryskiej. Poemat odnosi się do alegorycznego położenia Polski. Narratorowi, opłakującemu straszny los narodu pozbawionego niepodległego bytu, Sybilla wyjaśnia przyczynę klęski i wskazuje drogę do zmartwychwstania, odwołując się do tradycji antycznej: „Nie zagrzebie waszego rodu ta mogiła: Troja na to upadła, aby Rzym zrodziła".Świątynia Sybilli (inny tytuł: Sybilla) Poema historyczne w 4 pieśniach, powst. 1801 (według A. Drogoszewskiego), wyd. bez wiedzy autora F. Bentkowski pt. Sybilla. Poema..., Lwów (Warszawa) 1818; odpis: zobacz poz. 55 t. 1; wyd. następne: wyd. 2 poprawione
} 
Streszczenie: W XXI wieku edukacja muzealna w Polsce rozwija się szczególnie dynamicznie, powstają nowoczesne, interaktywne muzea o atrakcyjnej architekturze i bogatym programie edukacyjnym (Muzeum Powstania Warszawskiego, Muzeum Chopina czy nowo otwarte Muzeum Historii Żydów Polskich POLIN lub będące jeszcze w trakcie budowy Muzeum Historii Polski, Muzeum Marszałka Józefa Piłsudzkiego i wiele innych). Działania edukacyjne skierowane są do zróżnicowanych odbiorców, zarówno grup zorganizowanych np. klas szkolnych, jak również do odbiorcy indywidualnego, dzieci, rodzin czy grup osób niepełnosprawnych, społecznie wykluczonych.

$\mathrm{W}$ prezentowanym artykule autorka przedstawia pierwsze polskie muzeum, utworzone z prywatnej inicjatywy i „potrzeby serca” przez księżną Izabelę z Flemmingów Czartoryską na przełomie XVIII i XIX wieku, kiedy Polska całkowicie zniknęła z map Europy i utraciła swoją suwerenność. Współczesny edukacyjny wymiar dziedzictwa kulturowego i muzealnego Polski jest szczególnie istotny w kontekście historycznych wydarzeń i zaangażowania społeczeństwa polskiego, wybitnych Polaków na rzecz trwania i przetrwania kultury polskiej. Analizując genezę polskiego muzealnictwa, powstawania pierwszych muzeów narodowych o wymiarze patriotycznym, również poza granicami kraju ( np. w Rapperswilu w Szwajcarii), autorka podkreśla znaczenie tych działań dla rozwoju polskiej myśli pedagogicznej, edukacji muzealnej i wychowania patriotycznego.

Słowa kluczowe: edukacja muzealna, wychowanie patriotyczne, dziedzictwo kulturowe, polskie muzea narodowe, edukacja kulturowa 